\title{
Pre-Analytic Sources of Error with the Serum PAG-Pregnancy Test for Cows
}

\author{
F. Stahmann ${ }^{1}$, M. Gauly ${ }^{2}$, U. Koenig von Borstel ${ }^{1} \&$ Wolfgang Holtz ${ }^{1}$ \\ ${ }^{1}$ Department of Animal Science, Georg-August-University Goettingen, Goettingen, Germany \\ ${ }^{2}$ Faculty of Science and Technology, Free University of Bolzano, Bozen, Italy \\ Correspondence: Wolfgang Holtz, Department of Animal Science, Georg-August-University Goettingen, \\ Albrecht-Thaer-Weg 3, 37075 Goettingen, Germany. Tel: 49-551-39-65605. E-mail: wholtz@gwdg.de
}

Received: May 5, 2015 Accepted: July 20, 2015 Online Published: September 15, 2015

doi:10.5539/jas.v7n10p40 URL: http://dx.doi.org/10.5539/jas.v7n10p40

\begin{abstract}
The pregnancy associated glycoprotein (PAG) test for pregnancy detection in cows necessitates transportation of blood samples to the laboratory. This investigation addresses preanalytic sources of error that might compromise its reliability. During shipping blood samples undergo substantial temperature fluctuations (Experiment 1). Temperatures of whole blood beyond $0^{\circ} \mathrm{C}$ had no effect, whereas freezing reduced measurements by $22 \%$ at $-10{ }^{\circ} \mathrm{C}$ and by $25 \%$ at $-20^{\circ} \mathrm{C}$ (Experiment 2). Freezing of blood with low PAG content (Experiment 3) caused an increase from 2.4 to $3.7 \mathrm{ng} / \mathrm{ml}(\mathrm{P}<0.01)$. Cryopreservation of serum with various PAG concentrations (Experiment 4) brought about increases to varying degrees. The presence of heparin and EDTA in collecting tubes had no effect on PAG measurements, whereas citrate caused an initial reduction, but remained stable thereafter (Experiment 5). In blood stored six months at chilling temperature no change in PAG values occurred as long as samples contained heparin or EDTA (Experiment 6). In Experiment 7 vortexing of whole blood showed no effect, whereas freezing and dilution with water seriously compromised results. In summary, to obtain reliable PAG measurements, contamination with water must be avoided; freezing of whole blood or serum and the use of collecting tubes containing citrate will result in inaccuracies without altogether distorting results. High ambient temperature, physical agitation and long term storage at chilling temperature in the presence of heparin or EDTA will have no impact. PAG determination in blood may thus be considered a reliable pregnancy test for cows in most situations.
\end{abstract}

Keywords: blood test, cow, PAG, pregnancy associated glycoprotein, pregnancy detection

\section{Introduction}

Pregnancy diagnosis is an essential component of effective reproductive management in the dairy industry. Pregnancy can be diagnosed via rectal palpation with or without the support of ultrasonography, milk progesterone test or, more recently, measurement of pregnancy associated glycoproteins (PAGs) in blood or, in lactating cows, in milk. PAGs have their origin in the placenta of pregnant cows (Zoli, Beckers, Wouters-Ballman, Closset, Falmagne, \& Ectors, 1991; Hughes, Green, Garbayo, \& Roberts, 2000). PAG concentration in blood may be determined by radioimmunoassay (RIA) (Sasser, Ruder, Ivani, Butler, \& Hamilton, 1986; Zoli, Guilbault, Delhaupt, Benitez Ortiz, \& Beckers, 1992) or enzyme-linked immunosorbent assay (ELISA) using monoclonal (Green et al., 2005) or polyclonal antibodies (Friedrich \& Holtz, 2004, 2010). From day 28 of pregnancy onward PAG levels in pregnant cows will exceed $2.0 \mathrm{ng} / \mathrm{ml}$. At that stage the reliability of diagnosis approaches $94 \%$ (Friedrich \& Holtz, 2010). Although the popularity of the PAG test is increasing (our laboratory offers the service since 2005), little information is available concerning potential sources of error that might compromise its reliability. In this investigation blood was exposed to various effects that might act between collection and analysis of blood samples and could conceivably have an impact on the outcome of the PAG pregnancy test.

\section{Material and Methods}

All blood samples used in this sequence of experiments, with the exception of Experiment 4, originated from a single commercial farm and were taken by the same person by puncturing the abdominal vein (Vena epigastrica superficialis) with a sterile disposable needle (Braun Sterican $1.20 \times 40 \mathrm{~mm}$ ). Blood samples of about $3 \mathrm{ml}$ were 
collected into 5ml-test tubes (Sarstedt, Numbrecht, Germany) and shipped to the laboratory on crushed ice. They were stored in a refrigerator at $7{ }^{\circ} \mathrm{C}$ for one day before being centrifuged for $10 \mathrm{~min}$ at $3000 \mathrm{xg}$ to obtain serum that was analyzed (in duplicate) for bPAG1-content by competitive double antibody ELISA as described by Friedrich and Holtz (2010). The minimum detectable level of the assay was $0.4 \mathrm{ng} / \mathrm{ml}$ and inter- and intra-assay $\mathrm{CV}$ at $0.8 \mathrm{ng} / \mathrm{ml}$ were $13.2 \%$ and $16.3 \%$, respectively.

\subsection{Experiment 1: Transport-Related Temperature Fluctuation}

A pilot study was conducted to get an impression as to temperature fluctuations blood samples are subjected to on the way from the farm to the laboratory. Temperature loggers (Tinytag Temperature Data logger; Range $40{ }^{\circ} \mathrm{C}$ to $+75{ }^{\circ} \mathrm{C}$; Part No 9903-0017) were mailed from farms at five different locations in Germany on five warm summer and two cold winter days. Temperature was recorded at 15 minute intervals and times of dispatch and arrival at the laboratory were noted.

\subsection{Experiment 2: Effect of Various Temperatures on Whole Blood}

From each of nine lactating dairy cows at an advanced stage of pregnancy (123 to 211 days) seven blood samples were drawn, three of which were exposed to $0{ }^{\circ} \mathrm{C},-10{ }^{\circ} \mathrm{C}$ and $-20^{\circ} \mathrm{C}$ for the duration of 14 days, three to $+8{ }^{\circ} \mathrm{C},+20^{\circ} \mathrm{C}$ and $+40{ }^{\circ} \mathrm{C}$ for the duration of $3 \mathrm{~h}$ and a control sample remained in the refrigerator at $+7{ }^{\circ} \mathrm{C}$ for $3 \mathrm{~h}$ until being assayed.

\subsection{Experiment 3: Effect of Storage of Whole Blood at $-20{ }^{\circ} \mathrm{C}$}

Two blood samples were drawn from each of 34 early pregnant (32 to 81 days) lactating dairy cows. Upon arrival at the laboratory one of the samples was analyzed immediately, the other was stored for two weeks at $-20{ }^{\circ} \mathrm{C}$ before being analyzed.

\subsection{Experiment 4: Effect of Cryopreservation of Serum with Various PAG Contents}

Blood samples sent in by farmers for pregnancy testing were split into half after centrifugation. One part of the serum was assayed immediately to provide the herd owners with the diagnostic result; the other was stored at $-20{ }^{\circ} \mathrm{C}$. Two weeks later the counterparts of samples with PAG levels $0.39-0.45 \mathrm{ng} / \mathrm{ml}, 0.75-0.95 \mathrm{ng} / \mathrm{ml}$, $1.58-1.93 \mathrm{ng} / \mathrm{ml}, 3.15-3.85 \mathrm{ng} / \mathrm{ml}$, and 6.30-7.70 ng/ml, respectively, were picked out, thawed and analyzed.

\subsection{Experiment 5: Effect of Anti-Coagulants}

Four samples were collected from each of ten lactating dairy cows, 55 to 92 days pregnant, one each into commercially available test tubes containing the anti-coagulants heparin (Sarstedt, $4 \mathrm{ml}, 16$ I.E. heparin $/ \mathrm{ml}$ ), EDTA (Sarstedt, $4 \mathrm{ml}, 1.8 \mathrm{ml}$ EDTA/ml), citrate (Greiner bio-one, Vacuette, $3.5 \mathrm{~mL}$ 9NC Coagulation sodium citrate $3.2 \%$ ) or no anti-coagulant. After two hours samples were centrifuged and analyzed.

\subsection{Experiment 6: Effect of Long-Term Storage of Blood at Chilling Temperature}

From each of eleven lactating cows, 55 to 92 days pregnant, one sample each was collected into a commercially available test tube containing citrate, heparin, EDTA or no anti-coagulant. After centrifugation part of the supernatant was aspirated and analyzed for PAG. The remaining samples in capped test tubes were kept in the refrigerator at $7{ }^{\circ} \mathrm{C}$ for six months. Thereafter samples were gently stirred with a glass probe, centrifuged once again and the supernatant was assayed for PAG.

\subsection{Experiment 7: Effect of Strain to Blood Cells}

Of four blood samples from each of ten lactating dairy cows, 97 to 133 days pregnant, one per cow was vortexed for 10 minutes at maximum intensity on a standard laboratory mixer (Vortex Genie 2); one was frozen at $-20{ }^{\circ} \mathrm{C}$, one was diluted with an equal part of distilled water and one remained untreated. All samples were then centrifuged and analyzed for PAG.

\subsection{Experimental Design and Statistical Analyses}

Experiments 2 to 7 were repeated three times to provide for replications. Samples were randomly distributed on 96-well microtiter plates. Each sample was pipetted in duplicate and means of the duplicates were assessed by the software Magellan (version 6.0). Using these means, the following linear mixed model was applied to Experiments 2, 3, 5 and 7:

$$
\mathrm{y}=\mu+\text { treatment }+ \text { plate }+ \text { animal }+e
$$

Where y represents the PAG value, $\mu$ the overall mean, "animal" and e are random factors (accounting for repeated measurements per animal), "plate" a blocking factor based on the distribution of samples to plates, and "treatment" the respective treatment method of the sample (Experiment 2: temperature prior to analysis [7 
classes], Experiment 3: cryopreservation of whole blood [2 classes], Experiment 5: anti-coagulants [4 classes]), Experiment 7: effect of strain to blood cells [4 classes].

The model for Experiment 4 (Cryopreservation of serum with various PAG-contents) was:

$$
\mathrm{y}=\mu+\text { treatment }+ \text { group }+ \text { treatment*group }+ \text { animal }+e
$$

Where y represents the PAG value, $\mu$ the overall mean, "animal" and e the random and residual effects (accounting for repeated measurements per animal), "group" the group according to the range of PAG values of the samples [6 classes], "treatment" the respective treatment method (fresh vs. frozen) of the sample, and "treatment X group" the interaction between treatment and group.

The model for Experiment 6 (Effect of long term storage of blood at chilling temperature) was:

$$
\mathrm{y}=\mu+\text { treatment }+ \text { agent }+ \text { treatment*agent }+ \text { animal }+e
$$

Where "treatment" represents the duration of storage (fresh vs. long-term storage in the refrigerator), "agent" the anti-coagulants (4 classes), "treatment X agent" the interaction of the two. The remaining variables were the same as described above.

\section{Results and Discussion}

Temperature loggers mailed to the laboratory from different locations took between two and five days to reach their destination. Despite protection provided by padded envelopes and, according to the weather service, relatively moderate weather conditions, recorded temperatures ranged from $-9{ }^{\circ} \mathrm{C}$ to $+34{ }^{\circ} \mathrm{C}$ (Figure 1). Under more drastic weather conditions more extreme temperature fluctuations might occur. Seelig et al. (2008) point out that environmental conditions and irregularities with transportation and storage of blood samples may seriously compromise the outcome of certain analyses. Therefore, in Experiment 2 the effect of temperature extremes on PAG measurements in whole blood from cows at an advanced stage of pregnancy (high PAG level) was investigated.

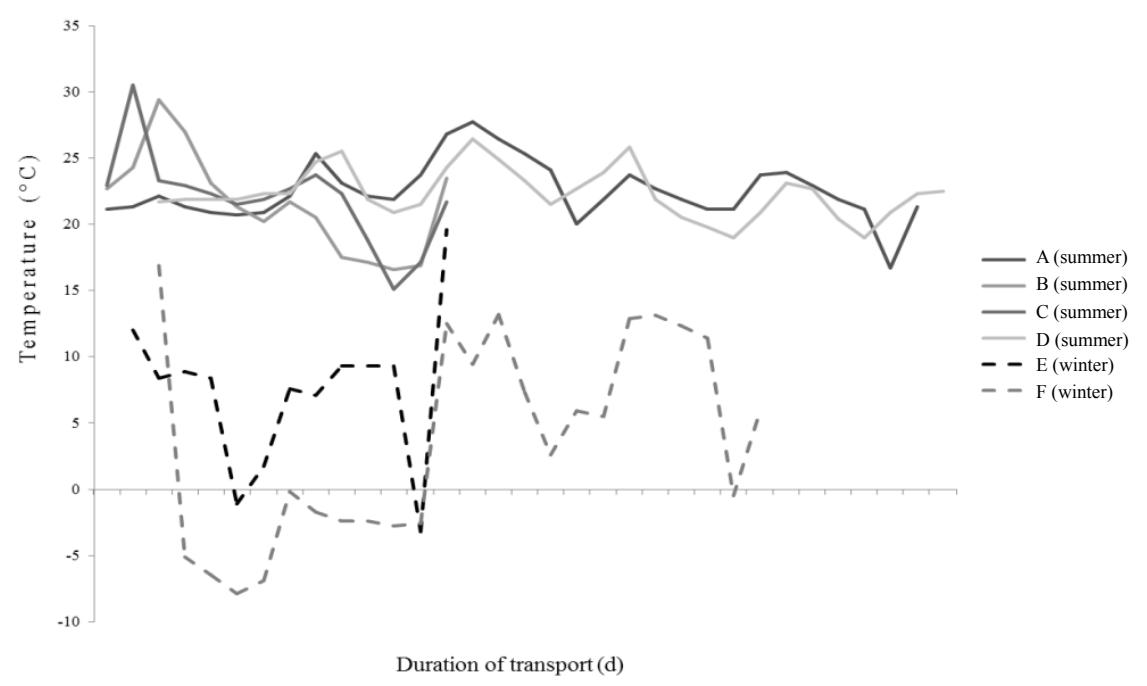

Figure 1. Temperatures recorded in packages mailed to the laboratory from various locations (A-F) during summer and winter months (Experiment 1)

As shown in Figure 2, temperatures above freezing caused no changes in PAG values. Tasker (1978), Wittwer, Boehmwald and Klaasen (1986) and Fontaine, Hamelin and Couture (1987) point out that blood proteins remain stable at temperatures above $0{ }^{\circ} \mathrm{C}$ and Guder (2002) mentions stability for six days at $4{ }^{\circ} \mathrm{C}$ to $8{ }^{\circ} \mathrm{C}$. In samples exposed to $-10{ }^{\circ} \mathrm{C}$ and $-20{ }^{\circ} \mathrm{C}$, however, PAG values were reduced by $22 \%$ and $25 \%$, respectively $(\mathrm{P}<0.01)$. According to Privalov (1990), denaturation of proteins at freezing temperatures cannot be ruled out, conceivably due to cell damage by ice crystal formation that may result in aberrations in $\mathrm{pH}$ and/or osmotic conditions (Heiss \& Eichner, 1995; Sonntag, 2009). Aberrations in molecular conformation might have an impact on binding sites for assay antibodies. These deviations are particularly relevant with slow freezing (Boegh-Soerensen, 1985; Farkas, 2007) and according to Seelig et al. (2008) it would be possible to avoid them by shock freezing in liquid nitrogen. 


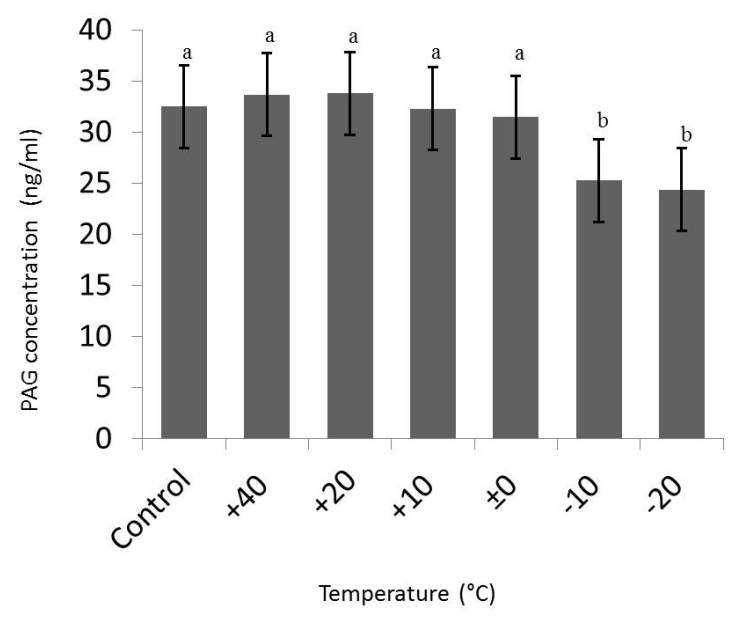

Figure 2. Effect of storage of whole blood from cows 123 to $211 \mathrm{~d}$ pregnant for $3 \mathrm{~h}$ at $0{ }^{\circ} \mathrm{C}, 20^{\circ} \mathrm{C}$ or $40{ }^{\circ} \mathrm{C}$, and for 2 weeks at $-10{ }^{\circ} \mathrm{C}$ or $-20{ }^{\circ} \mathrm{C}$ on the outcome of PAG measurement.

(means $\pm \mathrm{SE}$; a,b: $\mathrm{P}<0.01$ ) (Experiment 2)

Freezing of whole blood from early pregnant cows with relatively low PAG levels (Experiment 3 ) resulted in an increase in PAG values from $2.4 \mathrm{ng} / \mathrm{ml}$ in non-frozen serum samples to $3.7 \mathrm{ng} / \mathrm{ml}(\mathrm{P}<0.01)$. The discrepancy with the findings of Experiment 2 might be ascribed to differences in PAG molecules prevailing at an early vs. an advanced stage of pregnancy (Green et al., 2005), pertaining, according to Klisch et al. (2005), to differences in molecular mass or arrangement of carbohydrate side chains. As reported in Stahmann, Gauly, Holtz and Koenig-von Borstel (2013), this phenomenon necessitates application of different correction factors to compensate for the distorting effect of freezing on PAG measurements at different PAG levels.

In serum samples with different PAG levels cryopreserved at $-20{ }^{\circ} \mathrm{C}$ (Experiment 4) PAG concentration was elevated by $26 \%$ to $80 \%$ with an overall mean of $54 \%$ (Table 1). Individual variability was high, nonetheless, in the three groups with the highest deviation $(53 \%, 69 \%$ and $80 \%)$, the effect of freezing was statistically significant $(\mathrm{P}<0.01)$. The differences in degree of deviation might be associated with the respective stage of pregnancy with different PAG molecules prevailing (Green et al., 2005; Klisch, De Sousa, Beckers, Leiser, \& Pich, 2005).

Table 1. Effect of cryopreservation of serum containing various concentrations ( $\mathrm{ng} / \mathrm{ml}$ blood) of PAG (Experiment 4)

\begin{tabular}{|c|c|c|c|c|c|c|}
\hline \multirow{2}{*}{ PAG concentration } & \multirow{2}{*}{$\mathrm{n}$} & \multicolumn{2}{|c|}{ Prefreezing } & \multicolumn{2}{|c|}{ Postfreezing } & \multirow{2}{*}{ Difference $\%$} \\
\hline & & Mean & SE & Mean & SE & \\
\hline $0.39-0.45$ & 6 & $0.45^{\mathrm{a}}$ & 0.52 & $0.81^{\mathrm{b}}$ & 0.40 & +80 \\
\hline $0.75-0.95$ & 6 & $0.87^{\mathrm{ab}}$ & 0.54 & $1.23^{\mathrm{bc}}$ & 0.43 & +41 \\
\hline $1.58-1.93$ & 6 & $1.69^{\mathrm{c}}$ & 0.52 & $2.85^{\mathrm{d}}$ & 0.41 & +69 \\
\hline $3.15-3.85$ & 6 & $3.99^{\mathrm{d}}$ & 0.53 & $6.12^{\mathrm{e}}$ & 0.42 & +53 \\
\hline $6.30-7.70$ & 6 & $6.78^{\mathrm{ef}}$ & 0.51 & $8.52^{\mathrm{f}}$ & 0.41 & +26 \\
\hline
\end{tabular}

Note. ${ }^{\text {abcdef }}$ Different superscripts indicate differences between prefreezing and post freezing as well as between PAG concentrations $(\mathrm{P}<0.05)$.

According to Scheiffarth, Goetz and Cerny (1965) and Tasker (1978) molecular structure is maintained in blood stored at $-20{ }^{\circ} \mathrm{C}$, albeit Seelig et al. (2008) stress that, in order to achieve reliable results, freezing and thawing protocols ought to be carefully standardized.

It is not unusual to use test tubes with anti-coagulants when collecting blood. The data presented in Figure 3 (Experiment 5) indicate that, in the case of heparin and EDTA, no deviation is to be expected. In citrate 
containing test tubes, however, PAG values were significantly reduced $(\mathrm{P}<0.01)$. Heparin acts by inactivating thrombin and blocking the activity of several clotting factors and plasmin (Mollison, 1989) whereas citrate is a chelating agent blocking the calcium-dependent step in the cascade of events leading to clotting by sequestering the calcium ions required for catalytic action, a mode of action quite similar to that of EDTA (Auld, 1995). We have no plausible explanation why citrate would bring about a decrease in PAG whereas the other coagulants do not. According to Seelig et al. (2008) and Lippi et al. (2013), the ratio of citrate to blood is critical. In the present study blood was collected directly into the collecting tube, therefore the ratio was not standardized. It is unlikely, however, that this can serve as explanation.

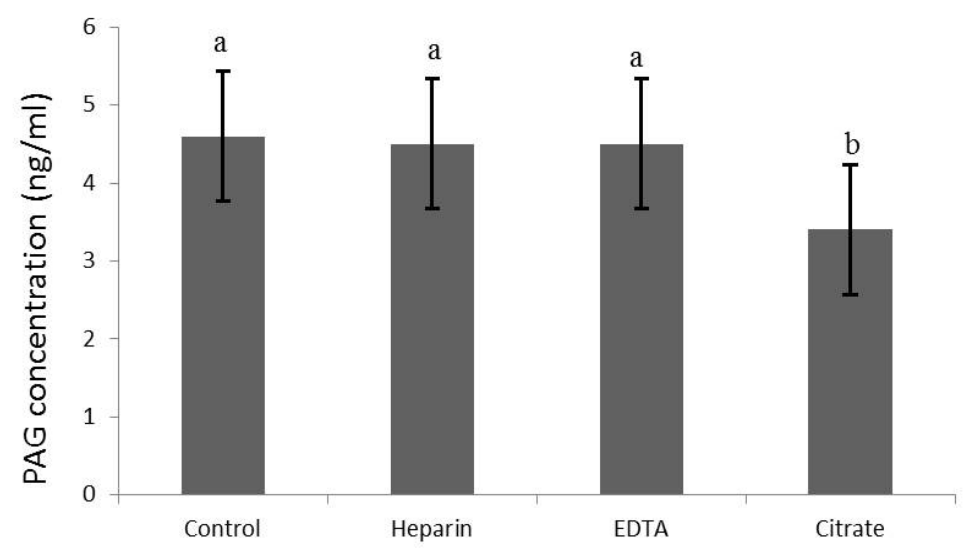

Figure 3. Effect of anti-coagulants on PAG determination in whole blood of cows 55 to $92 \mathrm{~d}$ pregnant (means \pm $\mathrm{SE} ; \mathrm{a}, \mathrm{b}: \mathrm{P}<0.01)($ Experiment 5)

In blood samples contained in heparin or EDTA containing test tubes that were left in the refrigerator for six months (Experiment 6), PAG levels remained unaltered (Table 2). In citrate-containing tubes there was an initial decline by $26 \%$ with no further change to speak of; much the same as in Experiment 4.

Table 2. Effect of chilled storage of blood for 6 months and the effect of various anticoagulants (Experiment 6)

\begin{tabular}{|c|c|c|c|c|c|}
\hline \multirow{2}{*}{ Anticoagulants } & \multirow{2}{*}{$\mathrm{n}$} & \multicolumn{2}{|c|}{ Fresh } & \multicolumn{2}{|c|}{ After storage } \\
\hline & & Mean & $\mathrm{SE}$ & Mean & $\mathrm{SE}$ \\
\hline None (Control) & 11 & $4.6^{\mathrm{b}}$ & 0.82 & $3.2^{\mathrm{a}}$ & 0.83 \\
\hline Heparin & 11 & $4.5^{\mathrm{b}}$ & 0.82 & $4.7^{\mathrm{b}}$ & 0.84 \\
\hline EDTA & 11 & $4.5^{\mathrm{b}}$ & 0.82 & $4.2^{\mathrm{b}}$ & 0.83 \\
\hline Citrate & 11 & $3.4^{\mathrm{a}}$ & 0.83 & $3.0^{\mathrm{a}}$ & 0.83 \\
\hline
\end{tabular}

Note. ${ }^{\mathrm{ab}}$ Different superscripts indicate differences between fresh and stored samples as well as between anti-coagulants $(\mathrm{P}<0.05)$.

This reflects the amazing stability of the PAG molecule, especially in view of the fact that, after 6 months, the serum had assumed a mucilaginous consistency making for difficult handling and pipetting. In test tubes without anti-coagulant, PAG values were reduced by $30 \%$ from $4.6 \pm 0.8$ to $3.2 \pm 0.83 \mathrm{ng} / \mathrm{ml}(\mathrm{P}<0.01)$. This does not appear surprising, as chilling temperature will decelerate (Tasker, 1978; Halwachs-Baumann, 2011) but not completely prevent decomposition. Anti-coagulants, thus, exert preservative action. This is nowhere explicitly reported, however, it is known that EDTA acts as powerful antioxidant and Guder et al. (2002) state that anticoagulants have the purpose of preventing clotting and also ensuring maintenance of the original state. Wardrop (1995) also points out that anticoagulants are effective in preventing changes associated with storage.

The effect of physical strain to blood cells on PAG measurements, such as by vigorous shaking, freezing without cryoprotectant and osmotic strain was put to the test in Experiment 7. It is generally recommended to handle blood samples gently, swivel rather than shake them to avoid layering of proteins and electrolytes (Minuth, 2003; 
Kraft, 2005; Bruhn, 2011) and avoid agitation during transportation (Stankovic, 2004). However, PAG measurements after ten minutes of vortexing at maximum intensity were unaffected (Figure 4) although hemolysis was evident. Freezing, on the other hand, resulted in a reduction in PAG measurements by $44 \%$ ( $\mathrm{P}<$ 0.01), even more than in Experiment 2, and dilution with distilled water brought about substantial distortion.

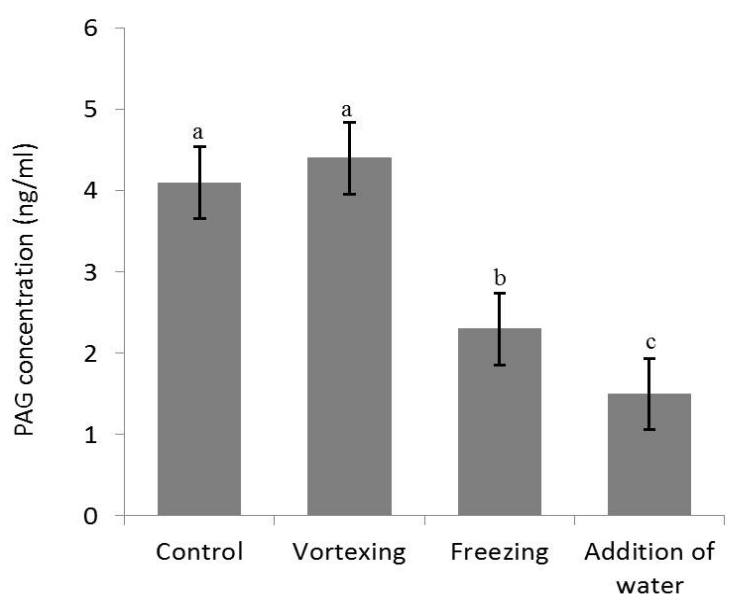

Figure 4. Effect of treatments expected to damage blood cells on the outcome of PAG measurements in whole blood from cows 97 to 133 days pregnant (means \pm SE; a,b: $\mathrm{P}<0.01)$ (Experiment 7)

Based on a dilution rate of $1: 1$ a reduction by $50 \%$ would have been expected; in actuality the value was reduced by $65 \%(\mathrm{P}<0.01)$. Blood samples contaminated with water, therefore, should be discarded and replaced by new ones.

From the results of the present investigation it may be concluded that, to obtain reliable PAG measurements, contamination of samples with water must be avoided. Freezing of whole blood or blood serum and the use of citrate-containing collecting tubes will cause a degree of distortion, but not altogether compromise results. High ambient temperature, physical agitation of blood, the use of heparin- or EDTA-containing collecting tubes (exerting a preservative effect) and long-term storage at chilling temperature will not impair the accuracy of measurements. PAGs thus are robust molecules and the test is not particularly prone to interference. It will, therefore, rapidly gain in popularity as a convenient and reliable means of pregnancy detection in cattle.

\section{Acknowledgements}

The authors owe thanks to J.F. Beckers from Liège University in Belgium for providing antiserum and tracer for the PAG assay.

\section{References}

Auld, D. S. (1995). Removal and replacement of metal ions in metallopeptidases. Methods in Enzymology, 248, 228-242. http://dx.doi.org/10.1016/0076-6879(95)48016-1

Boegh-Soerensen, L. M. (1985). Effects of freezing/thawing on foods. In R. K. Robinson (Ed.), Microbiology of Frozen Foods (pp. 41-82). Elsevier Applied Science Publishers, Essex, Great Britain.

Bruhn, H. D. (2011). Haeufige Fehlerursachen. In H. D. Bruhn, V. Hach-Wunderle, C. M. Schambeck \& R. E. Scharf (Eds.), Haemostaseologie fuer die Praxis: Sicher durch den klinischen Alltag. Schattauer, Stuttgart, Germany.

Farkas, J. (2007). Physical methods of food preservation, freezing and frozen storage. In M. P. Doyle \& L. R. Beuchat (Eds.), Food Microbiology: Fundamentals and Frontiers (3rd ed., pp. 685-712). ASM Press, Washington DC, USA.

Fontaine, M., Hamelin, N., \& Couture, Y. (1987). Stabilité des paramétres sanguins en fonction du temps, des conditions d'entreposage et de transport chez la vache. Le Médecin vétérinaire du Québec, 17, 71-77.

Friedrich, M., \& Holtz, W. (2004). Establishment of an ELISA to assess PAG-concentrations in blood and milk of dairy cows. Reproduction Abstract Series, 31, 21. 
Friedrich, M., \& Holtz, W. (2010). Establishment of an ELISA for measuring bovine pregnancy-associated glycoprotein in serum or milk and its application for early pregnancy detection. Reproduction of Domestic Animals, 45, 142-146. http://dx.doi.org/10.1111/j.1439-0531.2008.01287.x

Green, J. A., Parks, T. E., Avalle, M. P., Telugu, B. P., Mclain, A. L., Peterson, ... Roberts, R. M. (2005). The establishment of an ELISA for the detection of pregnancy-associated glycoproteins (PAGs) in serum of pregnant cows and heifers. Theriogenology, 1481-1503. http://dx.doi.org/10.1016/j.theriogenology.2004.07.011.

Guder, W. G., Ehret, W., Fonseca-Wollheim, F., Heil, W., Mueller-Plathe, O., Schmitt, Y., ... Zawta, B. (2002). Die Qualitaet diagnostischer Proben. Journal of Laboratory Clinical Medicine, 26, 267-283.

Halwachs-Baumann, G. (2011). Stoerfaktoren in Labormedizin-Klinik-Praxis-Fallbeispiele (2nd ed.). Springer Publishers, Vienna and New York.

Heiss, R., \& Eichner, K. (1995). Tiefgefrieren von Lebensmitteln. Einfrieren, Grundlagen. In R. Heiss \& K. Eichner (Eds.), Haltbarmachen von Lebensmitteln. Chemische, physikalische und mikrobiologische Grundlagen der Verfahren (3rd ed., pp. 156-164). Springer, Berlin, Germany. http://dx.doi.org/10.1007/978-3-662-07664-4_7

Hughes, A. L., Green, J. A., Garbayo, J. M., \& Roberts, R. M. (2000). Adaptive diversification within a large family of recently duplicated, placentally expressed genes. National Academy of Sciences, 49, 3319-3323. http://dx.doi.org/10.1073/pnas.97.7.3319

Klisch, K., De Sousa, N. M., Beckers, J. F., Leiser, R., \& Pich, A. (2005). Pregnancy associated glycoprotein-1, $-6,-7$, and -17 are major products of bovine binucleate trophoblast giant cells at midpregnancy. Moecular Reproduction and Development, 71, 453-460. http://dx.doi.org/10.1002/mrd.20296

Kraft, W. (2005). Fehlermoeglichkeiten. In W. Kraft \& M. Duerr (Eds.), Klinische Labordiagnostik in der Tiermedizin (pp. 18-34). Schattauer, Stuttgart, Germany.

Lippi, G., Becan-McBride, K., Behúlová, D., Bowen, R. A., Church, S., Delanghe, J., ... Simondic, A.-M. (2013). Preanalytical quality improvement: In quality we trust. Clinical and Chemical Laboratory Medicine, 51, 229-241. http://dx.doi.org/10.1515/cclm-2012-0597

Minuth, W. W. (2003). Serumgewinnung. In W. Minuth, R. Strehl \& K. Schumacher (Eds.), Zukunftstechnologie Tissue Engineering (p. 95). Wiley-VCH Verlag, Weinheim, Germany. http://dx.doi.org/10.1002/3527603069

Mollison, P. L. (1989). Further observations on the patterns of clearance of incompatible red cells. Transfusions, 29, 347-354. http://dx.doi.org/10.1046/j.1537-2995.1989.29489242803.x

Privalov, P. L. (1990). Cold denaturation of proteins. Biochemistry and Molecular Biology, 25, $281-306$. http://dx.doi.org/10.3109/10409239009090612

Sasser, R. G., Ruder, C. A., Ivani, K. A., Butler, J. E., \& Hamilton, W. C. (1986). Detection of pregnancy by radioimmunoassay of a novel pregnancy-specific protein in serum of cows and a profile of serum concentrations during gestation. Biology of Reproduction, 35, 936-942. http://dx.doi.org/10.1095/biolreprod35.4.936

Scheiffarth, F., Goetz, H., \& Cerny, R. (1965). Zur Frage der Gefrierdenaturierung von Serumproteinen. Zeitschrift fuer Klinische Chemie, 3, 81-84.

Seelig, H.-P., Koch, A., Muller, E., Schurek, J. O., Seelig, C. A., \& Stauch, T. (2008). Verarbeitung und Lagerung von Blutproben. Praeanalytik (3rd ed., pp. 103-1099). Alexander Thielbeer Druckerei \& Verlag, Ettlingen, Germany.

Sonntag, O. (2009). Praeanalytik und ihr Einfluss auf die Analytik. Retrieved from http://www.oequasta.at/download/veranstaltungen/ppt/2009_Linz_Sonntag.pdf

Stahmann, F., Gauly, M., Holtz, W., \& Koenig-von Borstel, U. (2013). A note on the correction for the effect of freezing on the outcome of pregnancy-associated glycoprotein measurement in blood and serum of cows. Journal of Dairy Science, 96, 6520-6524. http://dx.doi.org/10.3168/jds.2013-6734

Stankovic, A. K. (2004). The laboratory is a key partner in assuring patient safety. Clinics in Laboratory Medicine, 24, 1023-1035. http://dx.doi.org/10.1016/j.cll.2004.05.017

Tasker, J. B. (1978). Studies on the use of coulter chemistry in the veterinary laboratory. Cornell Veterinarian, 68 , 
480-505.

Wardrop, K. J. (1995). Selection of anticoagulant-preservatives for canine and feline blood storage. Veterinary Clinics of North America: Small Animal Practice, 25, 1263-1276. http://dx.doi.org/10.1016/S0195-5616(95)50153-6

Wittwer, F., Boehmwald, H., \& Klaasen, R. (1986). Efecto del tiempo, temperatura de conservacion y del anticoagulante (EDTA/NaF) en muestras para perfiles metabolicos. Archivos de Medicina Veterinaria, 18, 43-51.

Zoli, A. P., Beckers, J. F., Wouters-Ballman, P., Closset, J., Falmagne, P., \& Ectors, F. (1991). Purification and characterization of bovine pregnancy-associated glycoprotein. Biology of Reproduction, 45, 1-10. http://dx.doi.org/10.1095/biolreprod45.1.1

Zoli, A. P., Guilbault, L. A., Delhaupt, P., Benitez Ortiz, W., \& Beckers, J. F. (1992). Radioimmunoassay of a bovine pregnancy-associated glycoprotein in serum. Its application for pregnancy diagnosis. Biology of Reproduction, 46, 83-92. http://dx.doi.org/10.1095/biolreprod46.1.83

\section{Copyrights}

Copyright for this article is retained by the author(s), with first publication rights granted to the journal.

This is an open-access article distributed under the terms and conditions of the Creative Commons Attribution license (http://creativecommons.org/licenses/by/3.0/). 